\title{
Encapsulated vaginal pessary
}

\section{Jayasree Manivasakan*, Bupathy Arounassalame}

Department of Obstetrics and Gynaecology, Sri Manakula Vinayagar Medical College and Hospital, Kalitheerthalkuppam, Puducherry, India

Received: 24 June 2013

Accepted: 11 July 2013

\section{*Correspondence:}

Dr. Jayasree Manivasakan,

E-mail: drmjayasree1@yahoo.co.in

(C) 2013 Manivasakan J et al. This is an open-access article distributed under the terms of the Creative Commons Attribution Non-Commercial License, which permits unrestricted non-commercial use, distribution, and reproduction in any medium, provided the original work is properly cited.

\begin{abstract}
A ring pessary may be used for a prolapsed uterus. Forgotten pessaries produce many complications. We describe a case where the pessary was embedded in the vaginal mucosa. A 55 year old woman presented to the OPD with complaints of mass descending per vagina. On examination there was a pessary embedded in the posterior vaginal wall and it was removed under i.v. sedation. The pessary should be checked at 3 to 6 monthly intervals, and cleaned or changed as necessary. It is advisable to use polythene pessary which is inert. If pessaries are neglected and remain in situ for long periods of time (generally more than 4 months), serious complications can occur.
\end{abstract}

Keywords: Ring pessary, Embedded pessary, Pelvic organ prolapse

\section{INTRODUCTION}

Forgotten pessaries produce many complications like VVF, RVF, carcinoma etc., due to the erosive nature of the material the pessary is made of. We describe a case where the pessary was embedded in the vaginal mucosa without tissue reaction.

\section{CASE REPORT}

Mrs k., a 55 year old para 3, with last child birth 25 years back and attained menopause 5 years back, presented to the outpatient department complaining of mass descending per vagina of 5 years duration. She gave history of insertion of a ring pessary 3 years ago by a general practitioner for the above complaints. She was not given any instruction regarding follow up visits. There was no history of bleeding, discharge or pain. There was no difficulty in bladder or bowel habits. She had undergone laparotomy for benign ovarian tumour. She was a known hypertensive on beta blockers. There was no other significant history. On examination, a sub umbilical vertical healthy scar was present. Per speculum showed a polythene ring pessary displaced vertically in the antero posterior axis. The posterior semicircle of the pessary was embedded in the posterior vaginal wall with $2 \mathrm{~cm}$ band of vaginal epithelium covering the ring. There was no ulceration, discharge, necrosis or bleeding. Rectal examination revealed an intact rectal mucosa. All haematological and biochemical investigations were within normal limits.

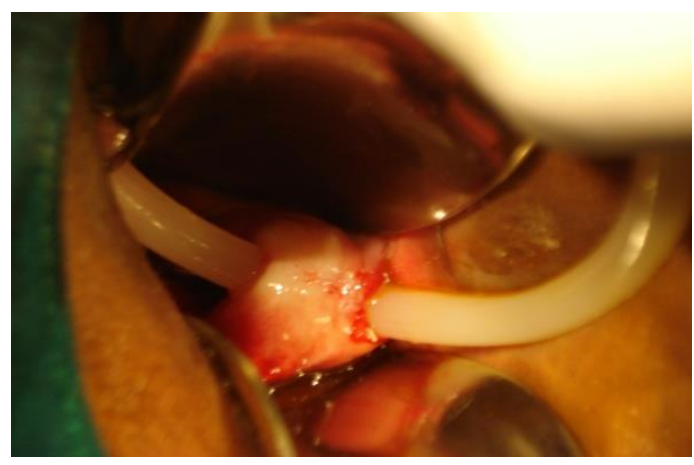

Figure 1: Polythene pessary in the posterior vaginal wall with no evidence of vaginitis. 
The pessary was removed under i.v. sedation by cutting the bridge of vagina with the scalpel and ligating the cut edges with catgut for haemostasis. The vaginal bed after removal was also smooth without any erosion. Reexamination of the rectum confirmed intact mucosa. Follow up of the patient after 6 weeks showed not only a healthy vagina and cervix but no descent of the cervix except minimal rectocele.

\section{DISCUSSION}

There are several case reports in the literature describing long forgotten pessaries. ${ }^{1-5}$ The complications include ulceration, necrosis, vaginitis, rectovaginal fistula, vesicovaginal fistula and carcinoma. The pessary in this case also would have ultimately eroded into the rectum given enough time but what is peculiar about this case is the absence of toxic tissue reaction and presence of a healthy bridge of vagina over the pessary (Figure 1). There is a similar case report describing encapsulation of the pessary. ${ }^{4,5}$ The pessaries are made of different material like PVC, silicone and polythene. Complications like rectovaginal fistula, vesicovaginal fistula etc., are common with either rubber or PVC pessaries compared to polythene pessaries which are soft and produce minimal tissue reaction. ${ }^{6}$ Selecting a right sized non irritant and pliable material like polythene and silicone and proper instructions to the patient regarding follow up make the long term use of pessary a safe alternative for surgery in selected cases.

\section{REFERENCES}

1. Kankam OK, Geraghty R. An erosive pessary. J R Soc Med. 2002 October; 95(10):507.

2. Powers K, Grigorescu B, Lazarou G, Greston WM, Weber T. Neglected pessary causing a rectovaginal fistula: a case report. J Reprod Med. 2008 Mar;53(3):235-7.

3. Nidhi S, Dahiya K. Forgotten Vaginal Pessary. The Internet Journal of Gynecology and Obstetrics 2011;14(2) ISPUB.

4. Stephan WB, Zaaijman Jdu T. Retention of a vaginal ring pessary in a postmenopausal patient. S Afr Med J. 2007 Aug;97(8):552.

5. Sivasuriya M. Cervical entrapment of a polythene vaginal ring pessary--a clinical curiosity. Aust N Z J Obstet Gynaecol. 1987 May;27(2):168-9.

6. Robertson DNS, Stoff FD. Advantages of "polythene" ring pessaries. Br Med J 1958;2:30.

DOI: $10.5455 / 2320-1770$. ijrcog20130945

Cite this article as: Manivasakan $\mathrm{J}$,

Arounassalame B. Encapsulated vaginal pessary.

Int J Reprod Contracept Obstet Gynecol 2013;2:458-9. 